\title{
REMOTE SENSING, LANDSCAPE AND ARCHAEOLOGY TRACING ANCIENT TRACKS AND ROADS BETWEEN PALMYRA AND THE EUPHRATES IN SYRIA
}

\author{
Minna Silver ${ }^{\mathrm{a}}$, Markus Törmäb ${ }^{\mathrm{b}}$, Kenneth Silver ${ }^{\mathrm{c}}$, Jari Okkonen ${ }^{\mathrm{d}}$, Milton Nuñez \\ a'Department of Archaeology, Mardin Artuklu University, 74200 Mardin, Turkey - minnaangelina@artuklu.edu.tr \\ ${ }^{\mathrm{b}}$ Aalto University, Espoo, Finland - markus.torma@aalto.fi \\ ${ }^{c}$ Independent Researcher, Mardin, Turkey - SilverKenneth@ hotmail.com \\ ${ }^{\mathrm{d}}$ University of Oulu, Oulu, Finland - jari.okkonen@ oulu.fi \\ ${ }^{\mathrm{e} U n i v e r s i t y ~ o f ~ O u l u, ~ O u l u, ~ F i n l a n d ~-~ m i l t o n . n u n e z @ o u l u . f i ~}$
}

KEY WORDS: Archaeology, Cultural Heritage, Remote Sensing, Surveying, Mapping, Syria, Palmyra, Jebel Bishri

\begin{abstract}
:
The present paper concentrates on the use of remote sensing by satellite imagery for detecting ancient tracks and roads in the area between Palmyra and the Euphrates in Syria. The Syrian desert was traversed by caravans already in the Bronze Age, and during the Greco-Roman period the traffic increased with the Silk Road and trade as well as with military missions annexing the areas into empires. SYGIS - the Finnish archaeological survey and mapping project traced, recorded and documented ancient sites and roads in the region of Jebel Bishri in Central Syria in 2000-2010 before the outbreak of the civil war in Syria. Captured data of ancient roads and bridge points bring new light to the study of ancient communication framework in the area. Archaeological research carried out by the project on the ground confirmed the authenticity of many road alignments, new military and water harvesting sites as well as civilian settlements, showing that the desert-steppe area was actively used and developed probably from the second century AD. The studies further demonstrated that the area between Palmyra and the Euphrates was militarily more organised already in the second and third centuries AD than earlier believed. Chronologically, the start of this coincided with the "golden age" of the Palmyrene caravans in the second century AD. Topography and landscape were integral parts of the construction of graves/tumuli as sign-posts guiding in the desert, as well as roads and all kinds of settlements whether military or civilian.
\end{abstract}

\section{INTRODUCTION}

The Finnish archaeological survey and mapping project SYGIS has been tracing, recording and documenting ancient sites in the mountainous region of Jebel Bishri belonging to the Palmyrides in Central Syria during 2000-2010. The area is located between Palmyra and the Euphrates river and covers ca. 1 million hectares of desert-steppe. The chief data sources used by the Finnish project in prospecting sites have constituted of satellite images. We have been following in the footsteps of Father A. Poidebard (1934) in using remote sensing methods in recording and mapping environmental features and archaeological remains in the region. The field work in situ in Syria has been vital for collecting GPS points for image rectification, capturing information of the material signatures of the nature and for empirical testing of the nature of the archaeological findings.

Captured data of ancient roads and bridge points brought new light to the study of the ancient communication framework in the area. Apart from the discovered Bronze Age and Iron Age sites witnessing to possible trade contacts, the existence and role of tracks and roads in the region especially bring fresh views on the eastern border zone of the Roman Empire. It should be observed that while mapping the region, A. Poidebard and R. Moutarde (1945) did actually not confirm the existence of all the mapped roads between Palmyra and the Euphrates on the ground, but assumed their existence by connecting known Roman forts and fortresses. Like in Poidebard's studies ancient itineraries and military tabulas from the Roman period have served as a good geographic basis in identifying some nodes of the road networks. For example, Ptolemy's Geographia from the $2^{\text {nd }}$ century AD (see, e.g., transl. and ed. by Stevenson) and the military tabulas such as the Tabula Peutingeriana as well as the Notitia Dignitatum dating from the Late Antiquity, list several Roman or Palmyrene sites in this region.

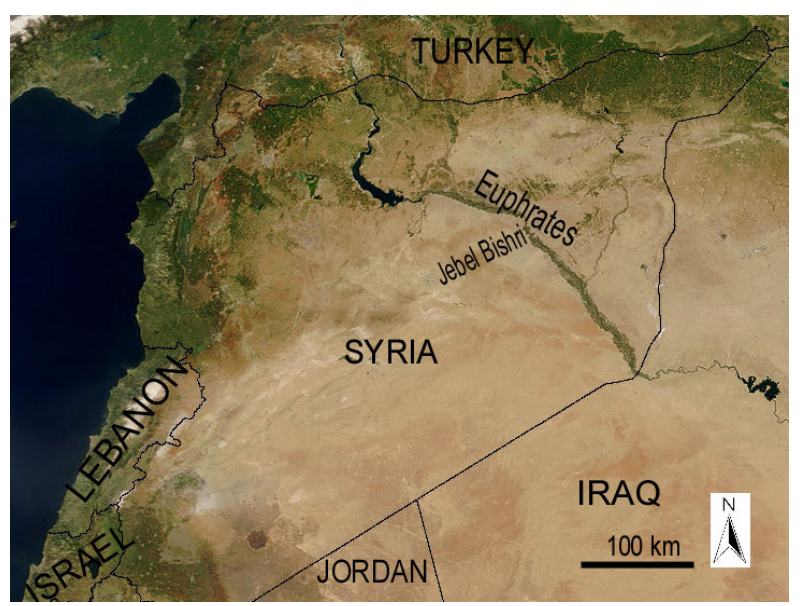

Figure 1. Syria and the location of Jebel Bishri.

The connection by a caravan road running through Tadmor (Palmyra) and the Syrian Desert to the Euphrates is already indicated in the Mari cuneiform texts dating from the Middle Bronze Age (18 ${ }^{\text {th }}$ century BC) (see, e.g., Joannès, 1997). Later on the Silk Road passed Palmyra (see, e.g., Rostovzeff, 1971), which was a famous caravan city in antiquity and enjoyed the privilege of autonomy of a varying degree during the Roman period. The Strata Diocletiana, the Diocletian road, which marked the Eastern limes of the Roman empire towards the desert, passed the city from the west to east, to the mountainous 
region of Jebel Bishri through the western oases of El Kowm and Qdeir, and finally reaching Sura at the Euphrates.

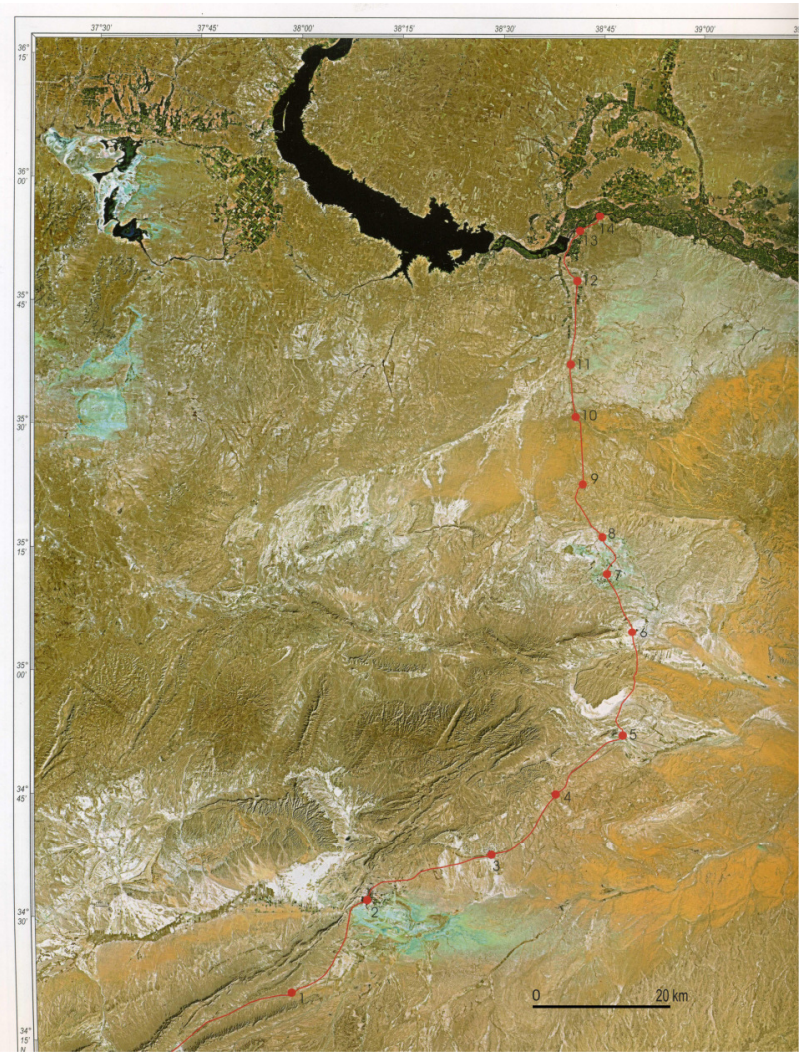

Figure 2. The Strata Diocletiana. A satellite map illustrating sites on the Strata Diocletiana passing Jebel Bishri: 1. Kh. alHallabat, 2. Palmyra, 3. Araq, 4. Helela, 5. Sukhne, 6. Oriza (Taibe), 7. El Kowm, 8. Qdeir, 9. Tell al-Fhada, 10. Holle, 11. Resafa-Sergiopolis, 12. Qusair al-Saila, 13. Sura I and 14. Sura II. Courtesy: GORS (SAS 2002).

Poidebard (1934) classified Roman roads found in the region into three categories: paved roads, track-roads and caravan roads. K. Butcher (2003) also noted that in Roman Syria in general there were three types of roads, of which the most elaborate ones were constructed in the roughest terrain such as marshy and rocky areas to contribute to stability and to connect cities and towns.

The second type of roads were simple compacted gravel roads between towns varying from $4 \mathrm{~m}$ to $7 \mathrm{~m}$ in width. The road surface was laid down of clayish soil mixed with gravel, on a foundation of ca. $20 \mathrm{~cm}$ thick stones. Sometimes the foundation was on a layer of bed stones.

The third type of road was the dirt-track road typical to the desert and steppe areas including the Strata Diocletiana. However, the road types mentioned by Poidebard and Butcher do not explicitly include rock-cut roads, which also are met within the Levant, including Syria. One of the most stunning Roman rock-cut roads can be found at Wadi Barada some 35 km west of Damascus (Burns, 1992).

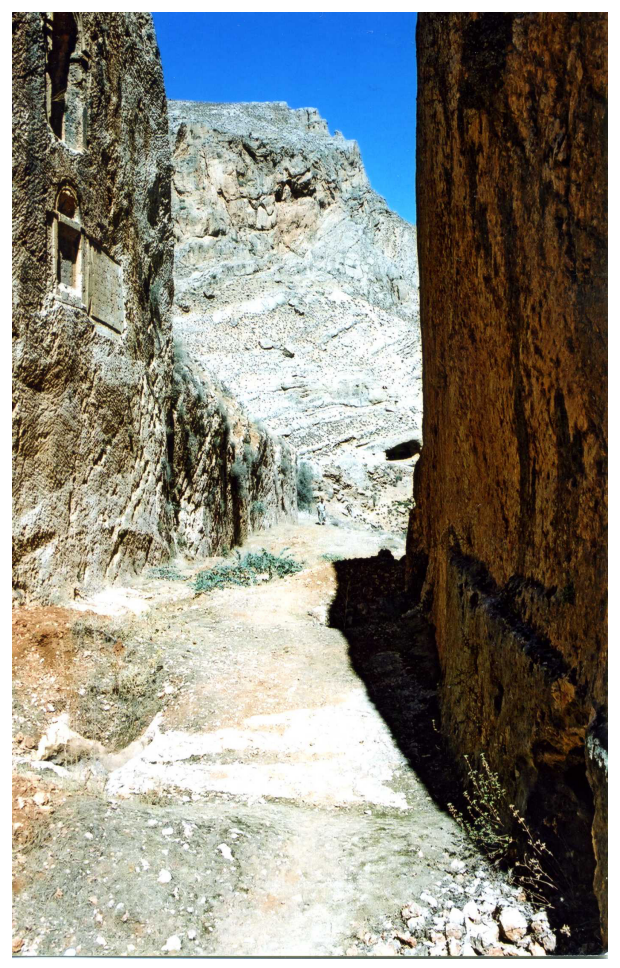

Figure 3. Rock-cut Roman road in Wadi Barada near Damascus in Syria.

\section{THE USE OF DATA IN REMOTE SENSING}

Following the aerial studies done in Syria in the 1920s to 1940s by RAF pilots (see, e.g., Thornton, 2006), or A. Poidebard (1934) and Sir Aurel Stein (1938-39), the availability of aerial photographs in the civilian sector decreased and cannot be compared to that of Jordan, where, for example, D. Kennedy has been carrying out aerial photographing for archaeological purposes for years, using it also for the detection of ancient roads. Therefore, during the last decade archaeologists also in Syria have increasingly turned to the use of satellite data sources in the remote sensing of archaeological remains.

The contrast of the environment and landscape in the region between Palmyra and the Euphrates is well visible in modern satellite imagery: the desert-steppe areas are clearly separated by the green and irrigated valley of the Euphrates.

GoogleEarth provides an easy way for anyone to approach the area from the satellite perspective. However, especially Landsat images elucidate the environmental data of the region, but the problem is that their spatial resolution only reaches up to $15 \mathrm{~m}$ in the panchromatic (black and white) channel. Various Landsat images can now also be downloaded free of charge via the internet. Classification of data, like carrying out cluster analyses, reveals different environmental variables affecting the region. Nowadays an explosive desertification is also visible in the region, and therefore sand has covered some of the areas which have been under study.

Declassified CORONA satellite photographs (USGS) from the 1960s have successfully been used in archaeological prospecting in the recent decade. D. Kennedy (1998), who initially introduced them to the Near Eastern Archaeology, was followed by several other archaeological projects in the region. For example, J. Ur (2003) satellite imagery for detecting Bronze Age roads radiating from particular sites in northern 
Syria, while our Finnish project in Syria, SYGIS, initially used them for detecting sites (Lönnqvist and Törmä, 2003).

The best spatial resolution of the CORONA photographs reaches $1.8 \mathrm{~m}$, whereas most of the photographs used by us only had the spatial resolution of $2.4 \mathrm{~m}$. CORONA photographs seemed also to reveal the best paved roads or rock-cut road alignments. Furthermore, we also used various other means in the data classification and in detecting roads, such as the socalled Sobel gradient.

In addition, the SPOT satellite images have provided a data source with a higher spatial resolution (panchromatic channel 5$2.5 \mathrm{~m}$ ) than the Landsat images (panchromatic channel c. $15 \mathrm{~m}$ ), and with SPOT images it has been possible to detect presentday villages and their road networks on the Euphrates. However, the low resolution of the Landsat images makes them less suitable for detecting road alignments compared to the high-resolution SPOT images. Anyhow, the highest spatial resolution $(0.6 \mathrm{~m})$ available in the civilian field is obtained by using the QuickBird images, which enabled us to detect dirt- or desert track roads too. The Sobel filtering applied to the QuickBird images also better enabled us to discern the roads.

\section{DETECTING DESERT TRACKS USED BY CARAVANS}

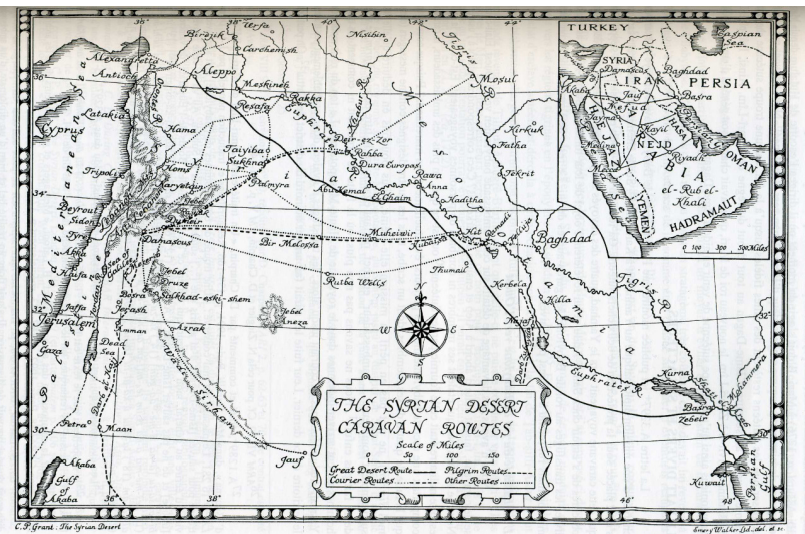

Figure 4. Map of the Syrian Desert Caravan Routes by C. P. Grant. Early $20^{\text {th }}$ century.

Apart from ancient maps, such as Ptolemy's Geographia and Tabula Peutingeriana, as well as more recent ones (Figure 4), remote sensing by aerial photographs and satellite imagery can be used for studying the caravan roads and their alignments in the desert. Here we present some satellite data sources and evaluate the visibility of such roads on them.

A desert track running from Palmyra towards Dura Europos on the Euphrates is traceable in the Landsat images displayed below of the 1970s and 1980s (see, e.g., Landsat-2 MSS-image 185/36, WRS 1, date 27.06.1975, channel 574 and Landsat-4 MSS-image 172/36, WRS-1, date 12.07.1983, channel 574, below).



Figure 5. Landsat-2 MSS-image 185/36 (WRS-1), date 27.06.1975, channel 574 .

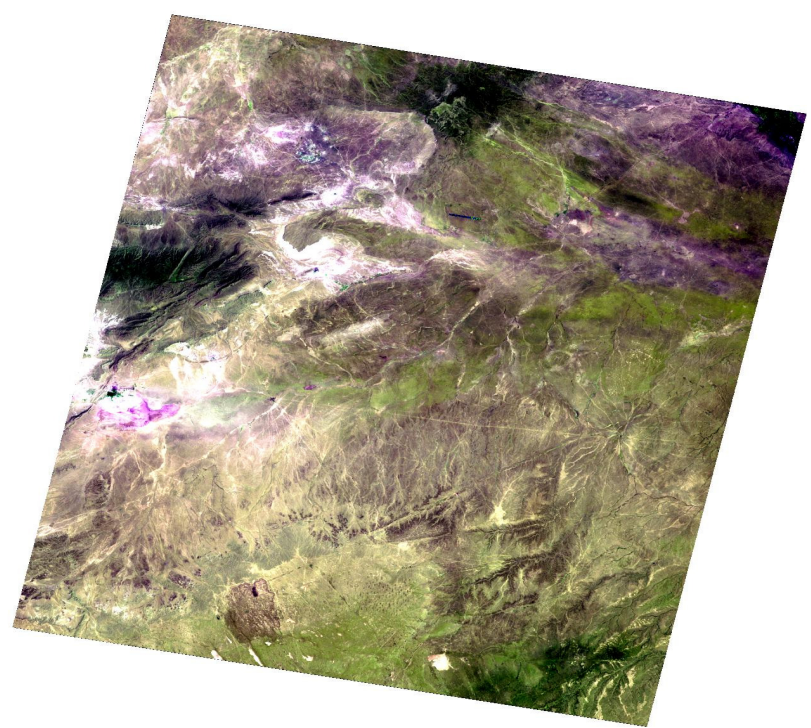

Figure 6. Landsat -4 MSS-image 172/36 (WRS-2), date 12.07.1983, channel 574 .

However, in the 1990s and 2000 the explosive desertification with sand masses blowing from the Arabian Peninsula has increased in strength and covered the desert tracks so that following the alignment of the road in these latest images by using remote sensing is impossible (see, e.g., Landsat-4 TMimage 172/36, WRS-2, date 01.09.1990, channel 741, and Landsat-7 ETM-image 172/36, WRS-2, date 26.05.2001, channel 741 , below). 


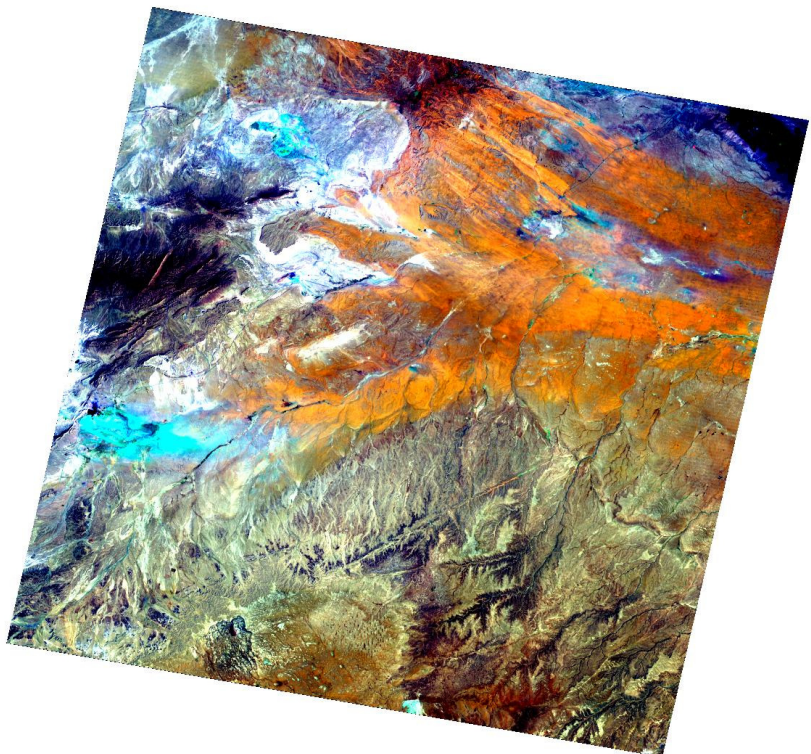

Figure 7. Landsat-4 TM-image 172/36 (WRS-2), date 01.09.1990, channel 741 .

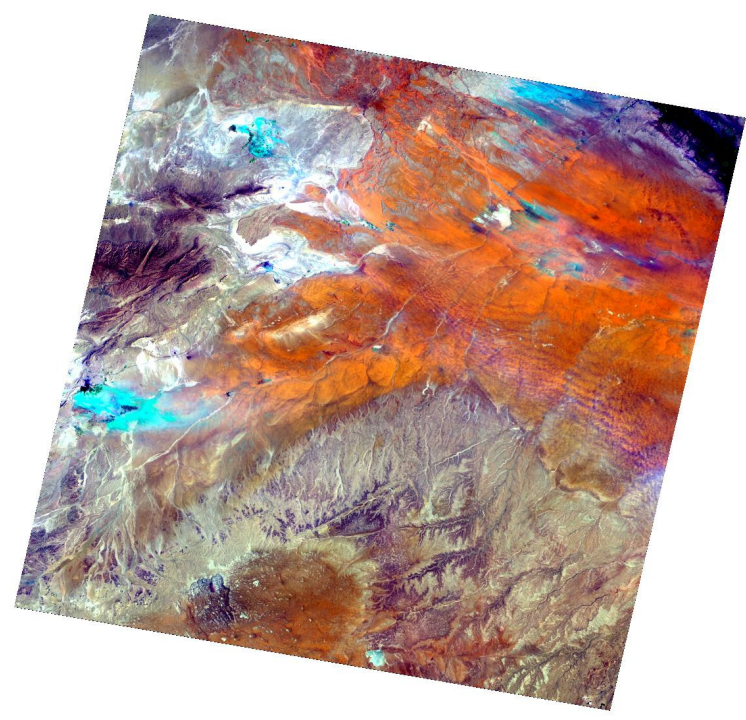

Figure 8. Landsat-7 ETM-image 172/36 (WRS-2), date 26.05.2001, channel 741 .

More recent caravan roads can be distinguished in the Landsat-7 images from the 1990s by following their straight alignment from the Arabian Peninsula in the direction of Jebel Bishri. Navigating along the caravan roads in the desert was facilitated by using stars and planets, especially Venus.

The Strata Diocletiana in Syria dated to c. AD 300 is characterized by mile stones, castra and castella. The unpaved Strata is also the continuation of the partly paved Via Nova Traiana in Jordan. However, on the western piedmont of Jebel Bishri part of the Strata Diocletiana followed the line formed of already existing sites, punctuated by oases, and mentioned in Ptolemy's Geographia from the second century AD (Lönnqvist et al., 2011). Each oasis has in fact Roman remains, and the caravan road passed the area for millennia. Water is an essential commodity in the area, and its existence is reflected in the green oases. Qanats or foqqaras, water channels, reflect from their part the organisation of the water harvesting. Caravan trade by early Arabs and Bedouins was also vibrant along the tracks as late as in the $16^{\text {th }}$ and $17^{\text {th }}$ centuries.

Cairns/tumuli clearly have served as land-marks for caravans in these desert and desert-steppe regions in the past. They are visible on ridges all over the Jebel Bishri horizon, and many of them apparently date from the Bronze Age. We have also recorded and documented special rujm markers (Figure 9.), i.e. heap of stones that were used to guide the people in desertsteppe areas on Jebel Bishri.

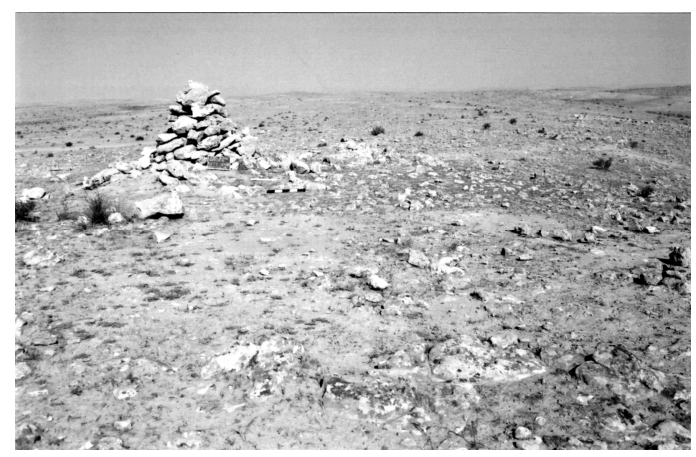

Figure 9. Rujm markers as path-finders on top of a hill.

In general, it is difficult to estimate how old the rujm markers are because associated finds are seldom found, and because Bedouins still construct new heaps for identifying their itineraries, even adding them on top of Bronze Age cairns. In addition, several desert tracks can be seen from satellite images on the mountain of Jebel Bishri itself, but it is also impossible to define their age by only using remote sensing data. Therefore, associated structures and archaeological small finds recorded on the ground seemed to be the only way of dating the periods of use of the roads (Lönnqvist et al., 2011).

\section{IDENTIFIED NEW ROADS ON THE EUPHRATES SIDE OF JEBEL BISHRI}

By inscriptions, the "golden age" of the caravans of Palmyra is dated to A.D. 131-161, thus covering the last years of the rule of the Roman Emperor Hadrian and the entire rule of Antoninus Pius. As we know, the city and the state of Palmyra used both caravans and ships in its extensive trade networks. M. Gawlikowski (1996) has also emphasized that the caravans of Palmyra must have utilized the Euphrates waterways at least downstream.

Having found old road alignments on the ground near the Late Roman - Byzantine fort of Tabūs on the Euphrates side of Jebel Bishri, our Finnish SYGIS project tried to trace their continuation with the help of a CORONA photograph (Figure 10). One of the roads, which we identified above the presentday Deir ez-Zor - Aleppo -road on a Pleistocene terrace, on the eastern side of Tabūs and c. $23 \mathrm{~km}$ northwest of Deir ez-Zor, was paved with marble/gypsum/calcite stones (H 13), while another one had been hewn nearby into the bedrock (H 15) c. 24 $\mathrm{km}$ northwest of Deir ez-Zor. The preserved length of the paved road $(\mathrm{H} 13)$ was a little more than one kilometre and its width was $5 \mathrm{~m}$ (Figure 11).

The structure of this road near Tabūs follows the normal building technique of Roman roads, also with regard to the profile of the road, which consisted of a layer of foundation stones followed by a ca. $30 \mathrm{~cm}$ thick layer of compacted sand 
and gravel and a road surface fully paved with stones. Further to the southeast of the village of 'Ayyāsh the continuation of the paved road (H 13), which had been identified on the Pleistocene terrace and which was running along the right bank of the Euphrates and the direction of the channel, was further traced on a CORONA photograph dating from the 1960s.

A stretch of the road alignment over one kilometre in length (L 6) appeared near the village of 'Ayyāsh on a high spatial resolution CORONA photograph, but was not visible in the SPOT images with the resolution from ca. 2.5 to $5 \mathrm{~m}$ or in the Landsat images which had a $15 \mathrm{~m}$ resolution and dated from the recent decades. It seems that modern constructions and environmental changes have affected the visibility of the road in recent decades.

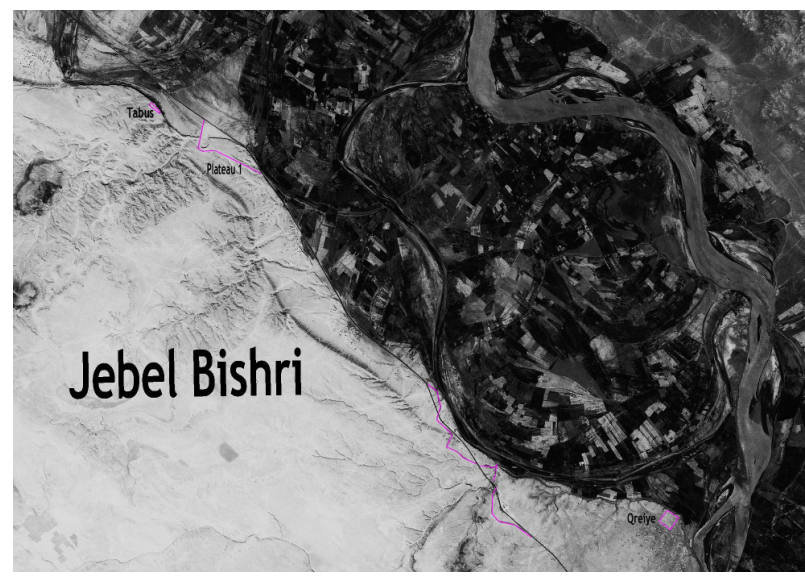

Figure 10. An ancient road alignment detected on a CORONA photograph along the Euphrates between the Late Roman forts of Tabūs and Qreiye.
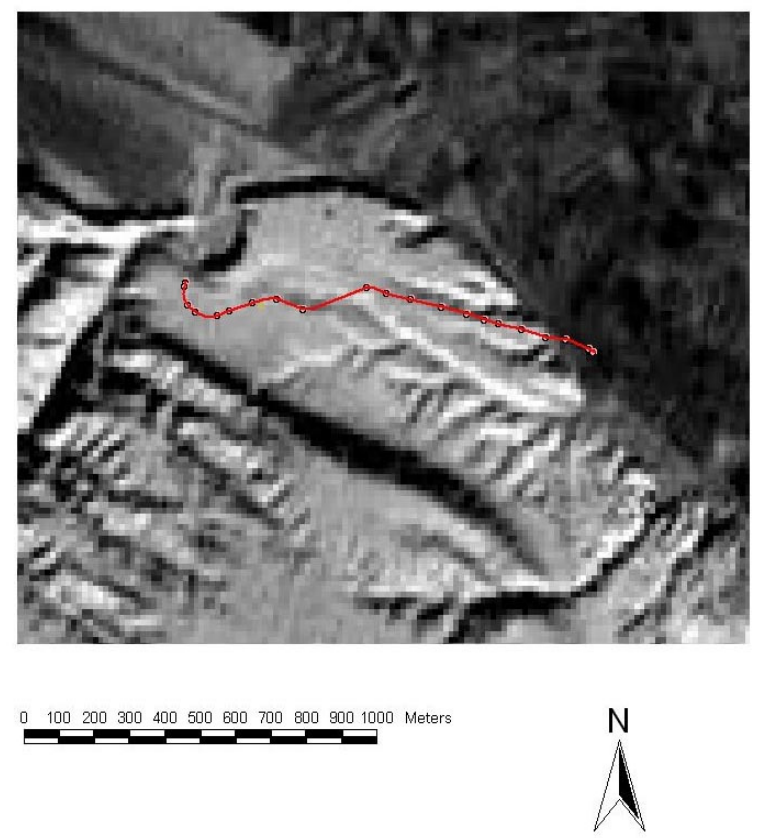

Figure 11. An ancient road alignment H 13 plotted with GPS waypoints on a Landsat image, which displays a Pleistocene terrace (Plateau 1) on the Euphrates. A close-up.

The topography and location of the road was the best possible one: being located on the Pleistocene terrace, the road was not vulnerable for annual flooding and sedimentation like in the lower river valley. Near 'Ayyāsh the road showed numerous layers of construction, including crushed gypsum and paving represented by the so-called Macadam structure. Associated pottery collected along these road alignments near Tabūs and 'Ayyāsh generally dated from the Late Roman period, but there were also examples of Bronze Age pottery indicating that there may have been an earlier road connecting the sites on the right bank of the Euphrates between Mari and sites in central Syria.

The road, at least its original alignment, could have served the central administration, caravans and military troops traversing on this side of the river, if not in the Bronze Age, then at least in the Roman period. Interestingly, the Euphrates used to be the border zone between the Romans and the Parthians (Edwell, 2007). Therefore, the right bank of the river would have provided the only river bank for constructing Roman roads in the second and third centuries $\mathrm{AD}$ as the opposite side and river bank was under the Parthian control, and this is where the Roman roads are found.

The other road (H 15) detected beneath the fort of Tabūs was hewn into the bed-rock, but as anticipated it did not lead to the fort (Lönnqvist et al,. 2006). The road was $3.5 \mathrm{~m}$ in width and it had cut ruts in the native rock to guide cart-wheels, improving traction and adding stability. The hewn stripes were added to prevent horses or donkeys from slipping, a technology known and used long before the Roman period in mountain passes.

When we followed the alignment of this road, it led c. $2 \mathrm{~km}$ up to the south to a high plateau on Jebel Bishri, which could have been used as a cemetery already in the Bronze Age (Lönnqvist et al,. 2009). The road could be dating from an earlier period as well because as said above, cutting ruts into the rock is an old technique.

Apart from the previously mentioned rock-cut road at Wadi Barada, comparable rock-cut roads have also recently been documented at Petra in Jordan (Haggrén et al., 2002; BenDavid, 2007) and in the "no-man's land" between Syria and Turkey (Wilkinson et al., 2007).

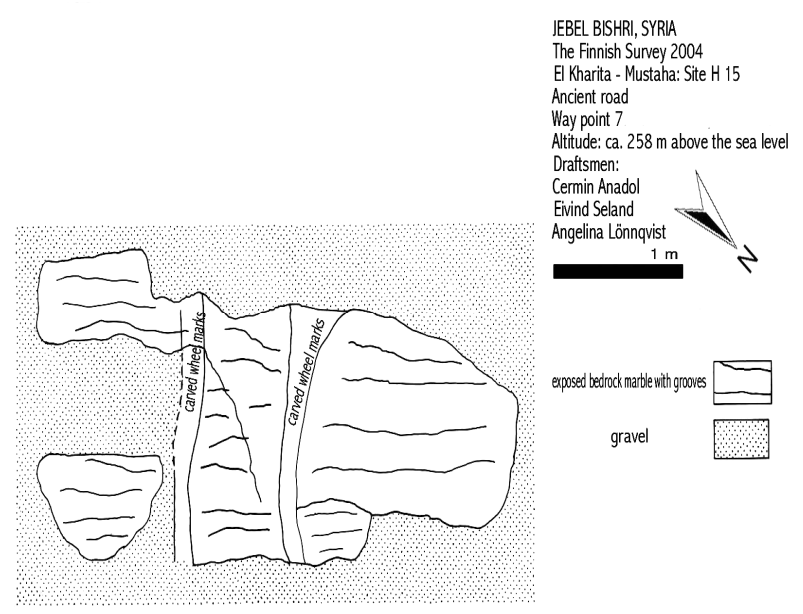

Figure 12. An ancient road H 15 with cart ruts cut into bed-rock on Jebel Bishri. 


\section{THE IDENTIFICATION AND FUNCTION OF THE "BISHRI CORRIDOR"}

By utilizing satellite images with a high spatial resolution, such as the QuickBird images, the Finnish survey and mapping project SYGIS also detected a rectangular Roman military fort or camp (K 1) in the central area of Jebel Bishri, c. $4 \mathrm{~km}$ southeast of the village of Ash-Shujiri.

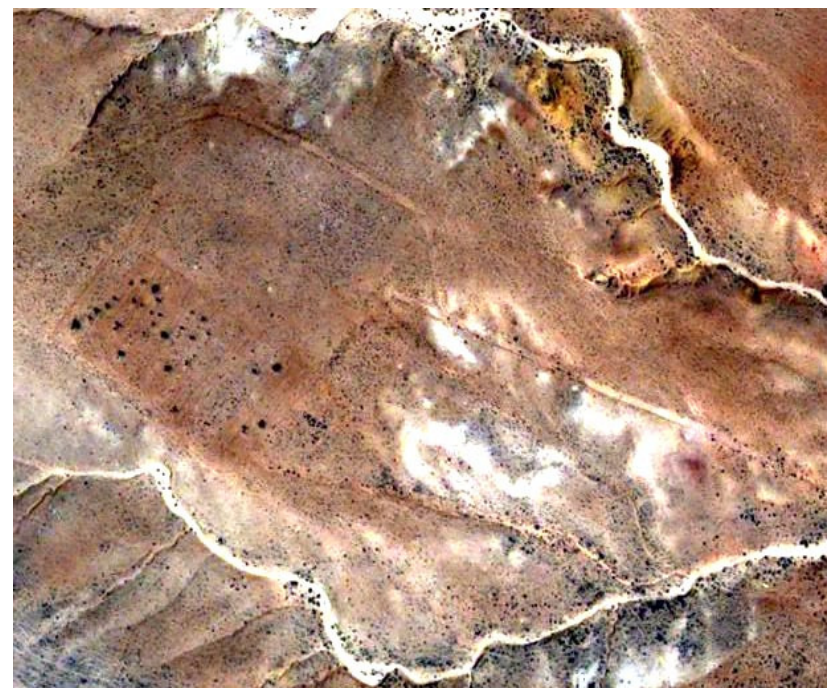

Figure 13. A Roman military camp K 1 in Ash-Shujiri, in the central area of Jebel Bishri as seen on a QuickBird satellite image.

In the image we also traced a road passing through the camp, a type of road usually called the via principalis. The authenticity of this playing card-type of fort or camp and the desert track entering it was confirmed on the ground by associated small finds. We mapped the site on the ground and collected numerous small finds such as Roman pottery, glass and one piece of a Roman armour scale. The track-road passing the camp had a straight alignment like the Roman desert tracks, and it continued down to the valley of Nadra where we further found many small Roman civilian sites (non-military). The track-road seemed to have formed a logistical corridor for providing supplies, and for messengers and troops moving between the fortresses on the Euphrates (Lönnqvist et al., 2011).

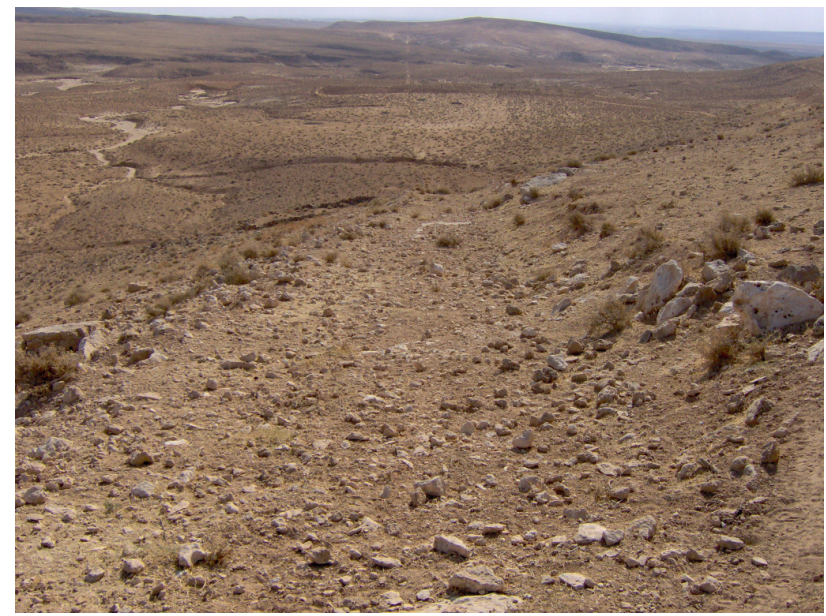

Figure 14 . The via principalis leading to the Roman military camp K 1 in Ash-Shujiri in central area of Jebel Bishri.
The Roman military camp ( $\mathrm{K}$ 1) was topographically well hidden in the landscape above a large wadi. Because of its location in a sheltered wadi on an elevated platform, it could easily have been protected. Furthermore, it is obvious that the site was chosen because it was also well protected from the harsh winds and climate prevailing up on the ridge of the mountain. Temporary forts or marching camps of this type were probably used for establishing new frameworks of defence on the Euphrates. The alignment of the road was not visible for the Parthians as it ran in the inner areas cross the mountain and not along the Euphrates. The date of the alSilverignment seems to fall into the second and third centuries $\mathrm{AD}$ when there was active construction phase of military sites on the Euphrates, including the garrison at Dura Europos. This would also coincide with the time when Palmyra was responsible for protecting Rome from the incursions or invasions coming from the desert (Lönnqvist et al., 2011).

Further to the east from the valley of Nadra, in the plain of Kharata, at Qseybe there is a Roman fortlet which we also recorded and documented. Poidebard had not visited the site on the ground, though he mapped it from the air and assumed that a connection existed from north to south along a road towards the Euphrates to the fort of Qreiye. The archaeological structures found at Qseybe and the associated small finds date from the second and third centuries $\mathrm{AD}$, from the time of Qreiye and Dura Europos, and therefore the connection is quite possible, even likely.

\section{CONCLUSIONS}

Palmyra in Syria was an important caravan city on the Silk Road during antiquity. Satellite imagery has been successfully used to reveal the ancient tracks and roads in its neighbourhood. The remote sensing and archaeological studies conducted by the Finnish archaeological survey and mapping project in Syria in 2000-2010 has shed new light on the study of ancient communications, the road networks and especially the defence systems of the eastern Roman border zone in the desert area of Jebel Bishri, a region which previously had received very little scholarly attention. The captured data of ancient roads and bridge points in conjunction with new archaeological documentations on the ground demonstrate, for example, that the area stretching north and east of Palmyra all the way to the Euphrates was more organised and militarily fortified already in the second and third centuries $\mathrm{AD}$ throughout Late Antiquity than earlier believed. The start of this development coincided with the "golden age" of the caravans of Palmyra in the second century AD, in the reign of Emperor Antoninus Pius mainly.

The authenticity of a number of road alignments and new military sites such as forts, fortlets or camps, water harvesting sites as well as civilian settlements was confirmed by the archaeological research showing that the desert-steppe area was actively being used and developed probably from the second century AD. Careful studies also showed that topography and landscape were integral part of the construction of graves/tumuli, roads and all kinds of settlements whether military or civilian. For example, the right topography and landscape offered visibility or cover, shelter or defence positions according to a need. The continuation of the ancient environmental awareness is followed by present-day Bedouins who still use the same networks of communication and old caravan roads. 
Navigating along the tracks or roads in the desert was facilitated by using stars and planets, especially Venus, or using fixed markers on the ridges such as ancient graves or heaps of stone. However, research of satellite images from different periods also sadly showed that an explosive man-made desertification with sand masses has increased in strength and covered many of the desert tracks and roads so that following the alignment of the ancient roads by using remote sensing is now difficult or entirely impossible.

\section{REFERENCES}

Ben-David, C., 2007. The Paved Road from Petra to the 'Arabah - Commercial Nabataean or Military Roman? in The Late Roman Army in the Near East from Diocletian to the Arab Conquest, Proceedings of a colloquium held at Potenza, Acerenza and Matera, Italy (May 2005), ed. by Lewin, A.S. and Pellegrini, P. with the aid of Fiema, Z.T. and Janniard, S., BAR International Series 1717, Oxford, Archaeopress, pp. 101-110.

Burns, R., 1992. Monuments of Syria, An Historical Guide, I.B. Tauris \& Co Ltd, Bridgend.

Butcher, K., 2003. Roman Syria and the Near East. London, The British Museum Press.

Edwell, P. M., 2007. Between Rome and Persia: the Middle Euphrates, Mesopotamia and Palmyra under Roman Control, Routledge Monographs in Classical Studies, London, Routledge.

Gawlikowski, M., 1996. Palmyra and its Caravan Trade, in Les Annales Archeologiques Arabes Syriennes, XLII, Special Issue Documenting the Activities of the International Colloquium: Palmyra and the Silk Road, pp. 139-144.

Haggrén, H., Nuikka, M., Junnilainen, H. and Järvinen, J., 2002. Photogrammetric Approach for Archaeological Documentation of an Ancient Road, in CIPA Heritage Documentation, Proceedings of the XVIII ${ }^{\text {th }}$ International Symposium of CIPA, Potsdam (Germany) Sept. 18-21, ed. Albertz, J., The ISPRS International Archives of Photogrammetry, Remote Sensing and Spatial Information Sciences, Vol. XXXIV-5/C7, Berlin, CIPA, pp. 108-113.

Joannés, F., 1997. Palmyre et les Routes du Desert au Début du Deuxième Millénaire av. J.-C., in M.A.R.I., Mari Annales de Recherches Interdisciplinaires 8, Paris, Éditions Recherche sur les Civilisations, pp. 393-415.

Kennedy, D., 1998. Declassified satellite photographs and archaeology in the Middle East: case studies from Turkey, in Antiquity, 72 (277), pp 553-561.

Lönnqvist, M. and Törmä, M., 2003. SYGIS - The Finnish Archaeological Project in Syria, in Proceedings of the XIX ${ }^{\text {th }}$ International Symposium CIPA 2003 (The ICOMOS \& ISPRS Committee for Documentation of Cultural Heritage), New Perspectives to Save Cultural Heritage, Antalya, Turkey, ed. Altan, M. Orhan, The ISPRS International Archives of the Photogrammetry, Remote Sensing and Spatial Information Sciences, Vol. XXXIV-5/C15, Istanbul, pp. 609-614.

Lönnqvist, M. with the contributions by Törmä, M., Nuñez, M., Lönnqvist, K., Whiting, M.S., Okkonen, J., Riihiaho, H., Nissinen, M., 2006. Archaeological Surveys of Jebel Bishri, The Preliminary Report of the Finnish Mission to Syria, 2000-
2004, in KASKAL,3, Rivista di storia, ambienti e culture del Vicino Oriente Antico, pp. 203-240.

Lönnqvist, M. with the contributions by Törmä, M., Lönnqvist, K., Okkonen, J., Herles, M., Königsdörfer, M., 2009. Archaeological Surveys of Jebel Bishri, The Preliminary Report of the Finnish Mission to Syria, 2005-2006, in KASKAL,6, Rivista di storia, ambienti e culture del Vicino Oriente Antico, pp. $1-42$.

Lönnqvist, M., Törmä, M., Lönnqvist, K. and Milton, N., 2011. Jebel Bishri in Focus, Remote Sensing, Archaeological Surveying, Mapping and GIS Studies of Jebel Bishri in Central Syria by the Finnish Project SYGIS, Eds. Minna Lönnqvist and Kenneth Lönnqvist, British Archaeological Reports, BAR International Series S2230, Archaeopress, Oxford.

Mouterde, R. and Poidebard, A., 1945. Le Limes de Chalcis: Organisation de la steppe en Haute Syrie Romaine, Bibliothèque Archéologique et Historique, Documents Aériens et Épigraphiques, Texte and Atlas, Paul Geuthner, Paris.

Poidebard, A., 1934. La trace de Rome dans le désert de Syrie: Le limes de Trajan a la conquête arabe, Recherces aériennes (1925-1932). Bibliothèque Archéologique et Historique, Tome XVIII, Texte, Atlas, Paris, Geuthner.

Rostovtzeff, M., 1932, repr. 1971, Caravan Cities. New York, AMS Press.

Stein, Aurel Sir, Kennedy, J., Gregory, S., 1985. Sir Aurel Stein's Limes Report: the full text of M. A. Stein's unpublished Limes report (his aerial and ground reconnaissances in Iraq and Transjordan in 1938-39), edited by D. L. Kennedy and S. Gregory, in British Archaeological Reports, International Series 272, 1985.

Thornton, A., 2006. Explorations in the Desert: The Photographic Collection of George and Agnes Horsfield, in Papers from the Institute of Archaeology, 17, pp. 93-100.

Ur, J., 2003. CORONA Satellite Photography and Ancient Road Networks: A Northern Mesopotamian Case Study, Antiquity 77 (295), pp. 102-115.

Wilkinson, T.,J., Peltenburg, E., McCarthy, A., Wilkinson, E.B., Brown, M., 2007. Archaeology in the Land of Carchemish: landscape surveys in the area of Jerablus Tahtani, in Levant 2006, 39, pp. 213-247. 